\title{
STUDY ON QUALITY ASSURANCE AND QUALITY MANAGEMENT IN HIGHRISE BUILDING CONSTRUCTION PROJECTS
}

\author{
Md Afsar Ali ${ }^{1}$, Masoom Reza ${ }^{2}$ \\ ${ }^{1} P G$ Student, Construction Technology \& Management, Al-Falah School of Engineering \& Technology, Al-Falah \\ University, Haryana, India \\ ${ }^{2}$ Civil Engineering Department, Al-Falah School of Engineering \& Technology, Al-Falah University, Haryana, India
}

\begin{abstract}
Due care is taken in the success of highrise building construction project, quality is the significant factors, and who is responsible for Managing ,Performing and verifying the quality related activities at Project Site. Every year a significant amount of the budget is spent for maintenance on highrise building construction project. The main objective to identify and evaluate the major factors effecting quality control measure of building construction projects in India. For analyzing the major factors for quality control measure in building construction project, adopting literature review and questionnaire surveys are used to assemble data. For the questionnaire survey Likert Scale (five point scale) is used for rating the opinions. The five point scale is transferred to Relative Importance Index for each factor. Afterward adopting Pareto analysis to evaluate the major factors for improving the quality in building construction project. A case study on Group Housing Residential Apartment project, Gurgaon has been undertaken to compare the result. This research identifies twenty major factors, in which the quality of workmanship is one of the major factors focus in construction site for improvement of quality followed by inadequate technical expert, not maintaining proper Design mix and other factors. From this research, by adopting Pareto Analysis(80-20 Rule) found that 80\% quality problem measurel improve by implementing 20 major factors on site. Further $20 \%$ quality problem improve by implementing remaining factors. With improvement of quality of project, save time and cost.
\end{abstract}

Keywords: Quality Management, Quality Assurance, Quality Plan, Quality tools, Relative importance index and Pareto analysis.

\section{INTRODUCTION}

Quality is one of the major factors in the success of building construction projects. Building construction project in India has been struggling with quality issues for many years. Every year a significant amount of the budget is spent for maintenance on building construction project.

In order to required a successful project, the three parameters namely time, cost and quality should be considered. The management mainly concerned with quality, time and cost but the majority of construction projects are procured namely time and cost. In the Quality Management System the main components are:-

\subsection{Quality Planning}

Purpose of this quality plan is to provide guidance for project executive, keeping in view the Quality system requirements as per ISO-9001. Due care is taken to clearly specify how the requirements have to be taken care of and who is responsible for Managing ,Performing and verifying the quality related activities at Project Site. A well documented quality system, comprising Quality Manual, Quality System Procedures, Work Instruction and Formats for creating record have been developed for execution of the Project

\subsection{Quality Assurance}

Quality assurance means owners must be ensure the investment of the money, which means contractors, should be ensure to the client that quality of the structure as per specification and drawings .Quality assurance is the process oriented and focuses on defect prevention provided by quality assurance department. It can be internal as well as external

\subsection{Quality Control}

Main objective of quality control is to be structure should be safe, reliable and durable by ensuring the work should be done as per specification and drawings. Quality control is product oriented and mainly focuses on defect identification that is often performed by quality control department.

\section{RESEARCH OBJECTIVE}

Based on the literature, Questionnaire Survey and the project chosen for study, the objective of the project is formulated as:

1 Identify the significant problem of High Rise Building Construction Project \& provide the rectification to them.

2 To specify relative importance index of the factors and to signify the rank of risk factors according to their importance. 
3 To construct a Pareto diagram which helps in identifying the top causes for the risks related with the construction project.

4 To explore how to ensure the quality assurance and quality management in building Construction project.

5 Identify the effectiveness of Quality Assurance \& Quality management Principles that could be implemented in Building Construction project

6 To create the quality awareness program in construction organization companies.

\section{LIMITATION OF THE RESEARCH}

1 The research focuses on Building construction companies only, other type of companies within construction industry will not be discussed in detail.

2 The data collected are limited to the year 2016 and 2017 Only. The research is limited to only India in which the respondents are randomly being selected and the factors varied with the size of project.

3 Quality assurance and quality control never been fully implemented in Building construction project in developing countries because quality management topic is almost new for developing countries.

\section{METHODOLOGY}

In this study, an approach of qualitative method is used, that is based on data that cannot be measured or counted but can be collected and interpreted through observation. The methodology for the work consists:

1 Adopting mix of literature Review.

2 Questionnaire base survey from different Projects of a company.

3 Questionnaire survey based on rating aspects on importance of five-point scale.

4 Analysis based on views of respondents of different projects of a company.

5 Adopting Pareto Analysis method

\section{DATA ANALYSIS}

Many Researchers was adopted relative importance index for analysis of data and ranking major factors. The same method is adopted in this study, data collected from respondents are converted in five point scale; the five point scale are transferred to relative importance index for each factor. The factors ranked in order of importance based on the relative importance indices values. The relative importance index is calculated by using below formula:

Relative Importance Index $(\mathrm{RII})=$

$$
\left(\frac{\sum W}{A \times N}\right)
$$

Where, $W=$ weightage given to each factor by the respondents and ranges From 1 to 5, $A=$ highest weight (i.e. 5 in this case) and $N=$ total number of respondents

\section{PARETO ANALYSIS (80-20 RULE)}

The aim of the Pareto chart is to find out most significant factors among set of factors. In quality control, it represents the most common sources of defects.

After obtaining Relative importance index for each factor, cumulative index and cumulative percentage of each factor is also determined. Thereafter draw the Pareto diagram in which Relative importance index are taken on primary axis as indicated by bar diagram in descending order and cumulative percentage of relative index are taken on secondary axis as indicated by line diagram in ascending order and also factors are taken on horizontal axis. Based on Pareto diagram interpret the result.

\section{QUALITY MANAGEMENT TOOLS AND TECHNIQUE}

The seven basic quality control tools used for problem solving and process improvement are as below and also shown in Figure. 1

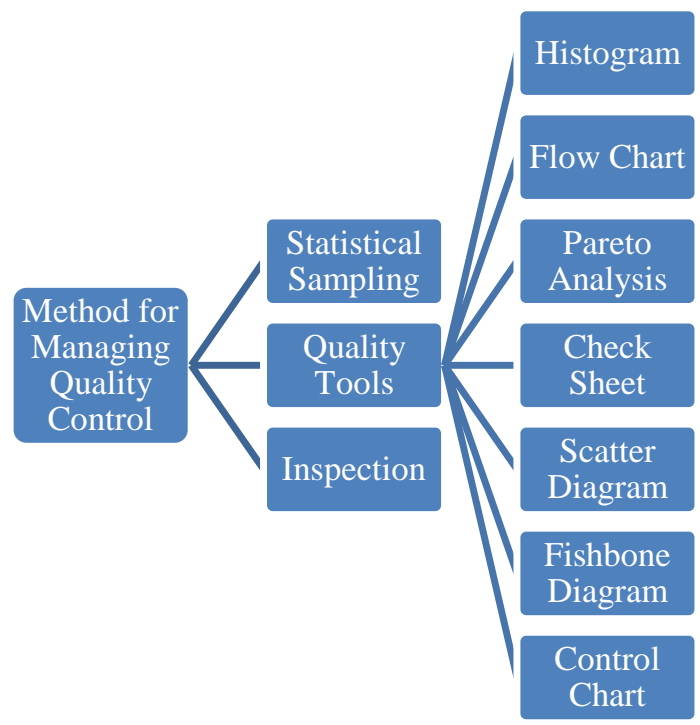

Fig-1: Quality Control Management Tools Chart

\section{DATA ANALYSIS AND DISCUSSION}

\subsection{Analysis of Data}

Total twelve respondents have filled up the questionnaire. For analysis of responses following steps are followed:

1 After getting of all twelve responses, Total Score is determined based on Rating scale (1-5). Calculation is shown in Table 1.

2 Afterwards, Relative Importance Index for each factors are calculated by using Relative importance index (RII) Method. A calculation is shown in Table 2. 
Table-1: Total Rating Score Calculation Sheet

\begin{tabular}{|c|c|c|c|c|c|c|c|c|c|c|c|c|c|c|}
\hline \multirow{2}{*}{$\begin{array}{l}\text { S. } \\
\text { No }\end{array}$} & \multirow{2}{*}{ Factor Name } & \multicolumn{12}{|c|}{ Respondents } & \multirow{2}{*}{$\begin{array}{l}\text { Total } \\
\text { Score }\end{array}$} \\
\hline & & 1 & 2 & 3 & 4 & 5 & 6 & 7 & 8 & 9 & 10 & 11 & 12 & \\
\hline 1 & Not study methodology of work & 4 & 3 & 3 & 4 & 3 & 4 & 4 & 5 & 2 & 4 & 3 & 3 & 42 \\
\hline 2 & $\begin{array}{l}\text { Testing certificate of Building } \\
\text { material }\end{array}$ & 5 & 4 & 5 & 5 & 5 & 4 & 4 & 4 & 5 & 5 & 4 & 4 & 54 \\
\hline 3 & Proper sampling and testing & 5 & 5 & 4 & 4 & 4 & 4 & 4 & 5 & 4 & 5 & 5 & 5 & 54 \\
\hline 4 & $\begin{array}{l}\text { Coordination with project purchase } \\
\text { department }\end{array}$ & 4 & 3 & 3 & 4 & 4 & 3 & 3 & 2 & 4 & 4 & 3 & 3 & 40 \\
\hline 5 & Inadequate management support & 4 & 4 & 4 & 3 & 4 & 3 & 4 & 4 & 4 & 2 & 3 & 3 & 42 \\
\hline 6 & Unwillingness of Project staff & 4 & 3 & 3 & 3 & 4 & 3 & 2 & 4 & 3 & 3 & 4 & 3 & 39 \\
\hline 7 & Curing and deshuttering schedule & 4 & 4 & 3 & 4 & 4 & 4 & 4 & 5 & 4 & 5 & 4 & 5 & 50 \\
\hline 8 & Quality of workmanship & 4 & 5 & 4 & 5 & 5 & 5 & 4 & 5 & 5 & 5 & 5 & 5 & 57 \\
\hline 9 & Laboratory at site & 5 & 5 & 5 & 4 & 4 & 5 & 5 & 4 & 4 & 5 & 4 & 5 & 55 \\
\hline 10 & Sequence of construction & 3 & 4 & 5 & 4 & 5 & 5 & 4 & 3 & 5 & 4 & 5 & 3 & 50 \\
\hline 11 & Review meeting with staff & 3 & 4 & 4 & 5 & 4 & 5 & 4 & 4 & 4 & 3 & 4 & 5 & 49 \\
\hline 12 & observe regular schedule & 4 & 4 & 4 & 4 & 4 & 4 & 4 & 3 & 3 & 2 & 4 & 4 & 44 \\
\hline 13 & Management commitment & 4 & 3 & 3 & 4 & 4 & 3 & 3 & 5 & 2 & 4 & 4 & 4 & 43 \\
\hline 14 & More paper work & 3 & 3 & 3 & 2 & 4 & 1 & 3 & 3 & 4 & 4 & 5 & 4 & 39 \\
\hline 15 & Problem with subcontractor work & 4 & 5 & 3 & 4 & 4 & 4 & 3 & 3 & 4 & 3 & 4 & 4 & 45 \\
\hline 16 & Ineffective communication & 4 & 4 & 4 & 4 & 3 & 3 & 4 & 4 & 4 & 4 & 4 & 4 & 46 \\
\hline 17 & Inadequate information & 3 & 4 & 3 & 2 & 4 & 4 & 3 & 3 & 5 & 3 & 4 & 4 & 42 \\
\hline 18 & Inadequate technical expert & 5 & 5 & 4 & 5 & 5 & 5 & 5 & 4 & 4 & 5 & 4 & 5 & 56 \\
\hline 19 & Increase of Building material cost & 4 & 4 & 4 & 5 & 4 & 5 & 3 & 4 & 4 & 3 & 3 & 4 & 47 \\
\hline 20 & Increase of project work time & 4 & 3 & 3 & 4 & 4 & 4 & 5 & 2 & 4 & 3 & 3 & 3 & 42 \\
\hline 21 & Environmental issues & 3 & 3 & 2 & 3 & 2 & 4 & 3 & 4 & 3 & 4 & 4 & 3 & 38 \\
\hline 22 & Unfairness in tendering/bidding & 4 & 4 & 4 & 4 & 4 & 3 & 4 & 4 & 4 & 3 & 4 & 4 & 46 \\
\hline 23 & Poor project planning & 4 & 3 & 4 & 3 & 4 & 4 & 3 & 4 & 3 & 4 & 3 & 4 & 43 \\
\hline 24 & Lack of quality planning & 5 & 4 & 4 & 5 & 4 & 5 & 4 & 5 & 4 & 4 & 3 & 3 & 50 \\
\hline 25 & Not maintaining proper Design mix & 4 & 5 & 4 & 5 & 5 & 5 & 4 & 5 & 5 & 4 & 5 & 5 & 56 \\
\hline 26 & $\begin{array}{l}\text { Vibrator during pouring of } \\
\text { concrete }\end{array}$ & 4 & 4 & 4 & 3 & 4 & 3 & 5 & 4 & 3 & 4 & 3 & 5 & 46 \\
\hline
\end{tabular}

Table-2: Relative Importance Index Calculation Sheet

\begin{tabular}{|c|l|c|c|c|c|c|c|c|c|c|c|c|c|c|c|}
\hline \multirow{2}{*}{$\begin{array}{c}\text { S. } \\
\text { No }\end{array}$} & \multicolumn{1}{|c|}{ Factor Name } & \multicolumn{1}{|c|}{$\begin{array}{c}\text { Total } \\
\text { Score }\end{array}$} & RII \\
\hline 1 & Not study methodology of work & 4 & 3 & 3 & 4 & 3 & 4 & 4 & 5 & 2 & 4 & 3 & 3 & 42 & 0.700 \\
\hline 2 & $\begin{array}{l}\text { Testing certificate of Building } \\
\text { material }\end{array}$ & 5 & 4 & 5 & 5 & 5 & 4 & 4 & 4 & 5 & 5 & 4 & 4 & 54 & 0.900 \\
\hline 3 & Proper sampling and testing & 5 & 5 & 4 & 4 & 4 & 4 & 4 & 5 & 4 & 5 & 5 & 5 & 54 & 0.900 \\
\hline 4 & $\begin{array}{l}\text { Coordination with project } \\
\text { purchase department }\end{array}$ & 4 & 3 & 3 & 4 & 4 & 3 & 3 & 2 & 4 & 4 & 3 & 3 & 40 & 0.667 \\
\hline 5 & Inadequate management support & 4 & 4 & 4 & 3 & 4 & 3 & 4 & 4 & 4 & 2 & 3 & 3 & 42 & 0.700 \\
\hline 6 & Unwillingness of Project staff & 4 & 3 & 3 & 3 & 4 & 3 & 2 & 4 & 3 & 3 & 4 & 3 & 39 & 0.650 \\
\hline 7 & Curing and deshuttering schedule & 4 & 4 & 3 & 4 & 4 & 4 & 4 & 5 & 4 & 5 & 4 & 5 & 50 & 0.833 \\
\hline 8 & Quality of workmanship & 4 & 5 & 4 & 5 & 5 & 5 & 4 & 5 & 5 & 5 & 5 & 5 & 57 & 0.950 \\
\hline 9 & Laboratory at site & 5 & 5 & 5 & 4 & 4 & 5 & 5 & 4 & 4 & 5 & 4 & 5 & 55 & 0.917 \\
\hline 10 & Sequence of construction & 3 & 4 & 5 & 4 & 5 & 5 & 4 & 3 & 5 & 4 & 5 & 3 & 50 & 0.833 \\
\hline 11 & Review meeting with staff & 3 & 4 & 4 & 5 & 4 & 5 & 4 & 4 & 4 & 3 & 4 & 5 & 49 & 0.817 \\
\hline 12 & observe regular schedule & 4 & 4 & 4 & 4 & 4 & 4 & 4 & 3 & 3 & 2 & 4 & 4 & 44 & 0.733 \\
\hline 13 & Management commitment & 4 & 3 & 3 & 4 & 4 & 3 & 3 & 5 & 2 & 4 & 4 & 4 & 43 & 0.717 \\
\hline 14 & More paper work & 3 & 3 & 3 & 2 & 4 & 1 & 3 & 3 & 4 & 4 & 5 & 4 & 39 & 0.650 \\
\hline
\end{tabular}




\begin{tabular}{|c|c|c|c|c|c|c|c|c|c|c|c|c|c|c|c|}
\hline 15 & Problem with subcontractor work & 4 & 5 & 3 & 4 & 4 & 4 & 3 & 3 & 4 & 3 & 4 & 4 & 45 & 0.750 \\
\hline 16 & Ineffective communication & 4 & 4 & 4 & 4 & 3 & 3 & 4 & 4 & 4 & 4 & 4 & 4 & 46 & 0.767 \\
\hline 17 & Inadequate information & 3 & 4 & 3 & 2 & 4 & 4 & 3 & 3 & 5 & 3 & 4 & 4 & 42 & 0.700 \\
\hline 18 & Inadequate technical expert & 5 & 5 & 4 & 5 & 5 & 5 & 5 & 4 & 4 & 5 & 4 & 5 & 56 & 0.933 \\
\hline 19 & Increase of Building material cost & 4 & 4 & 4 & 5 & 4 & 5 & 3 & 4 & 4 & 3 & 3 & 4 & 47 & 0.783 \\
\hline 20 & Increase of project work time & 4 & 3 & 3 & 4 & 4 & 4 & 5 & 2 & 4 & 3 & 3 & 3 & 42 & 0.700 \\
\hline 21 & Environmental issues & 3 & 3 & 2 & 3 & 2 & 4 & 3 & 4 & 3 & 4 & 4 & 3 & 38 & 0.633 \\
\hline 22 & Unfairness in tendering/bidding & 4 & 4 & 4 & 4 & 4 & 3 & 4 & 4 & 4 & 3 & 4 & 4 & 46 & 0.767 \\
\hline 23 & Poor project planning & 4 & 3 & 4 & 3 & 4 & 4 & 3 & 4 & 3 & 4 & 3 & 4 & 43 & 0.717 \\
\hline 24 & Lack of quality planning & 5 & 4 & 4 & 5 & 4 & 5 & 4 & 5 & 4 & 4 & 3 & 3 & 50 & 0.833 \\
\hline 25 & $\begin{array}{l}\text { Not maintaining proper Design } \\
\text { mix }\end{array}$ & 4 & 5 & 4 & 5 & 5 & 5 & 4 & 5 & 5 & 4 & 5 & 5 & 56 & 0.933 \\
\hline 26 & $\begin{array}{l}\text { Vibrator during pouring of } \\
\text { concrete }\end{array}$ & 4 & 4 & 4 & 3 & 4 & 3 & 5 & 4 & 3 & 4 & 3 & 5 & 46 & 0.767 \\
\hline
\end{tabular}

3 Based on Relative Importance Index, rearrangement of factors is done in descending order. The factors are ranked in order of importance based on Relative Importance Index. It is shown in Table 3.
4 Draw a line diagram for Ranking of quality control measure based on importance of Relative Index shown in Figure. 2

Table-3: Ranking Based on Relative Importance Index

\begin{tabular}{|c|c|c|c|}
\hline S. No. & Factor Name & $\begin{array}{c}\text { Relative importance } \\
\text { Index }\end{array}$ & Rank \\
\hline 1 & Quality of workmanship & 0.950 & 1 \\
\hline 2 & Inadequate technical expert & 0.933 & 2 \\
\hline 3 & Not maintaining proper Design mix & 0.933 & 2 \\
\hline 4 & Laboratory at site & 0.917 & 3 \\
\hline 5 & Testing certificate of Building material & 0.900 & 4 \\
\hline 6 & Proper sampling and testing & 0.900 & 4 \\
\hline 7 & Curing and deshuttering schedule & 0.833 & 5 \\
\hline 8 & Sequence of construction & 0.833 & 5 \\
\hline 9 & Lack of quality planning & 0.833 & 5 \\
\hline 10 & Review meeting with staff & 0.817 & 6 \\
\hline 11 & Increase of Building material cost & 0.783 & 7 \\
\hline 12 & Ineffective communication & 0.767 & 8 \\
\hline 13 & Unfairness in tendering/Bidding & 0.767 & 8 \\
\hline 14 & Vibrator during pouring of concrete & 0.767 & 8 \\
\hline 15 & Problem with subcontractor work & 0.750 & 9 \\
\hline 16 & Observe regular schedule & 0.733 & 10 \\
\hline 17 & Management commitment & 0.717 & 11 \\
\hline 18 & Poor project planning & 0.717 & 11 \\
\hline 19 & Not study methodology of work & 0.700 & 12 \\
\hline
\end{tabular}




\begin{tabular}{|l|l|l|l|}
\hline 20 & Inadequate management support & 0.700 & 12 \\
\hline 21 & Inadequate information & 0.700 & 12 \\
\hline 22 & Increase of project work time & 0.700 & 12 \\
\hline 23 & Coordination with project purchase department & 0.667 & 13 \\
\hline 24 & Unwillingness of Project staff & 0.650 & 14 \\
\hline 25 & More paper work & 0.650 & 14 \\
\hline 26 & Environmental issue & 0.633 & 15 \\
\hline
\end{tabular}

Ranking Of Quality Control Measure Factor

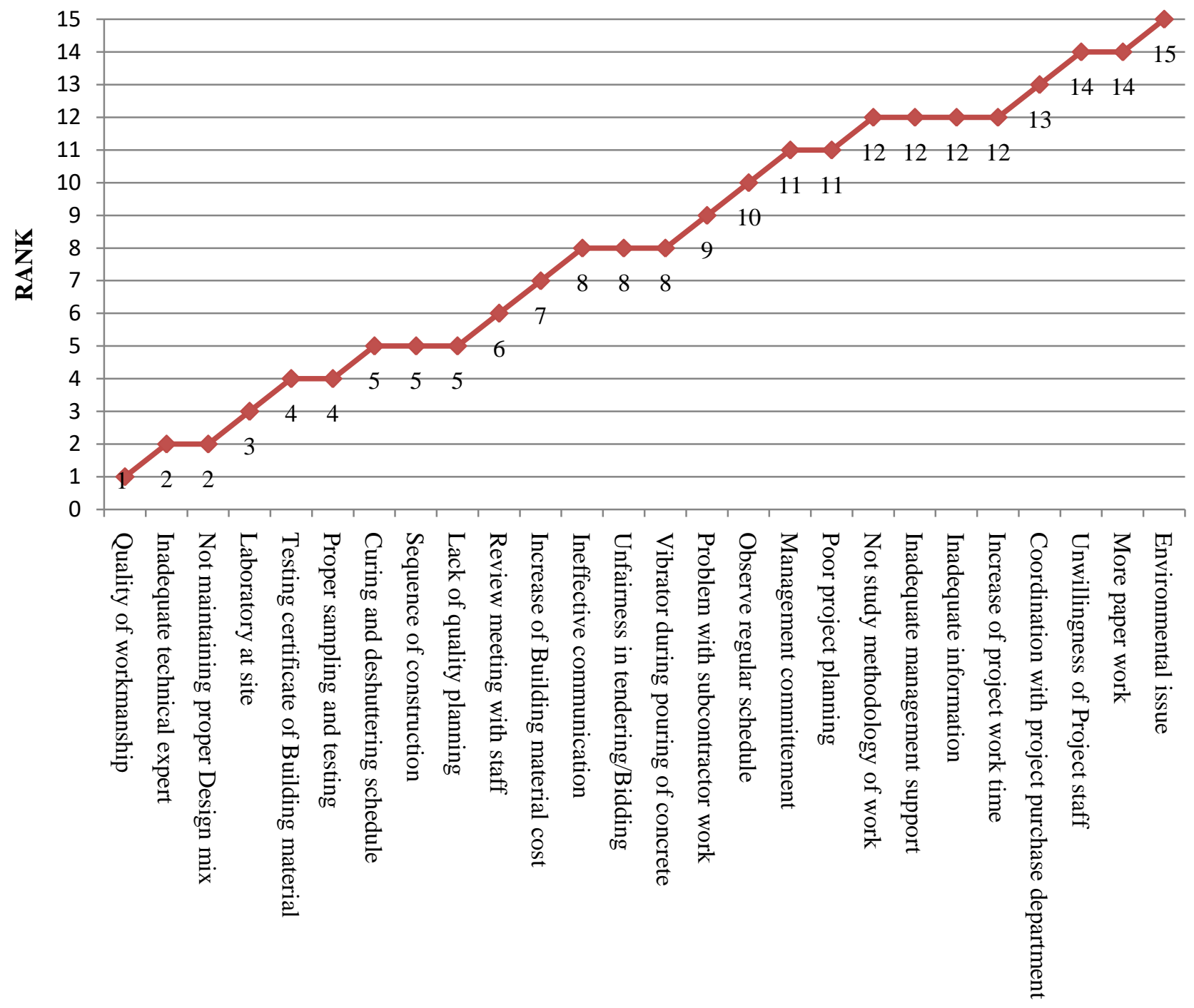

Fig-2: Ranking of Quality Control Measure

5 After obtaining importance based Relative importance index for each factor, cumulative index and cumulative percentage of each factor is determined by using Pareto Analysis (80 - 20 Rule). Calculation is shown in Table 4.
6 Draw the Pareto diagram in which Relative importance index are taken on primary axis as indicated by bar diagram in descending order and cumulative percentage of relative index are taken on secondary axis as indicated by line diagram in ascending order and also factors are taken on horizontal axis. It is shown in Figure 3. 
Table-4: Pareto analysis calculation sheet

\begin{tabular}{|c|c|c|c|c|}
\hline S. No & Factor Name & $\begin{array}{c}\text { Relative } \\
\text { importance Index }\end{array}$ & $\begin{array}{l}\text { cumulative } \\
\text { Index }\end{array}$ & $\begin{array}{l}\text { Cumulative } \\
\text { percentage }\end{array}$ \\
\hline 1 & Quality of workmanship & 0.950 & 0.950 & $4.69 \%$ \\
\hline 2 & Inadequate technical expert & 0.933 & 1.883 & $9.30 \%$ \\
\hline 3 & Not maintaining proper Design mix & 0.933 & 2.817 & $13.91 \%$ \\
\hline 4 & Laboratory at site & 0.917 & 3.733 & $18.44 \%$ \\
\hline 5 & Testing certificate of Building material & 0.900 & 4.633 & $22.88 \%$ \\
\hline 6 & Proper sampling and testing & 0.900 & 5.533 & $27.33 \%$ \\
\hline 7 & Curing and deshuttering schedule & 0.833 & 6.367 & $31.44 \%$ \\
\hline 8 & Sequence of construction & 0.833 & 7.200 & $35.56 \%$ \\
\hline 9 & Lack of quality planning & 0.833 & 8.033 & $39.67 \%$ \\
\hline 10 & Review meeting with staff & 0.817 & 8.850 & $43.70 \%$ \\
\hline 11 & Increase building material cost & 0.783 & 9.633 & $47.57 \%$ \\
\hline 12 & Ineffective communication & 0.767 & 10.400 & $51.36 \%$ \\
\hline 13 & Unfairness tendering/Bidding & 0.767 & 11.167 & $55.14 \%$ \\
\hline 14 & Vibrator during pouring of concrete & 0.767 & 11.933 & $58.93 \%$ \\
\hline 15 & Problem with subcontractor work & 0.750 & 12.683 & $62.63 \%$ \\
\hline 16 & observe regular schedule & 0.733 & 13.417 & $66.26 \%$ \\
\hline 17 & Management committement & 0.717 & 14.133 & $69.79 \%$ \\
\hline 18 & Poor project planning & 0.717 & 14.850 & $73.33 \%$ \\
\hline 19 & Not study methodology of work & 0.700 & 15.550 & $76.79 \%$ \\
\hline 20 & Inadequate management support & 0.700 & 16.250 & $80.25 \%$ \\
\hline 21 & Inadequate information & 0.700 & 16.950 & $83.70 \%$ \\
\hline 22 & Increase of project work time & 0.700 & 17.650 & $87.16 \%$ \\
\hline 23 & Coordination with project purchase department & 0.667 & 18.317 & $90.45 \%$ \\
\hline 24 & Unwillingness of Project staff & 0.650 & 18.967 & $93.66 \%$ \\
\hline 25 & More paper work & 0.650 & 19.617 & $96.87 \%$ \\
\hline \multirow[t]{2}{*}{26} & Environmental issue & 0.633 & 20.250 & $100.00 \%$ \\
\hline & TOTAL & 20.250 & & \\
\hline
\end{tabular}




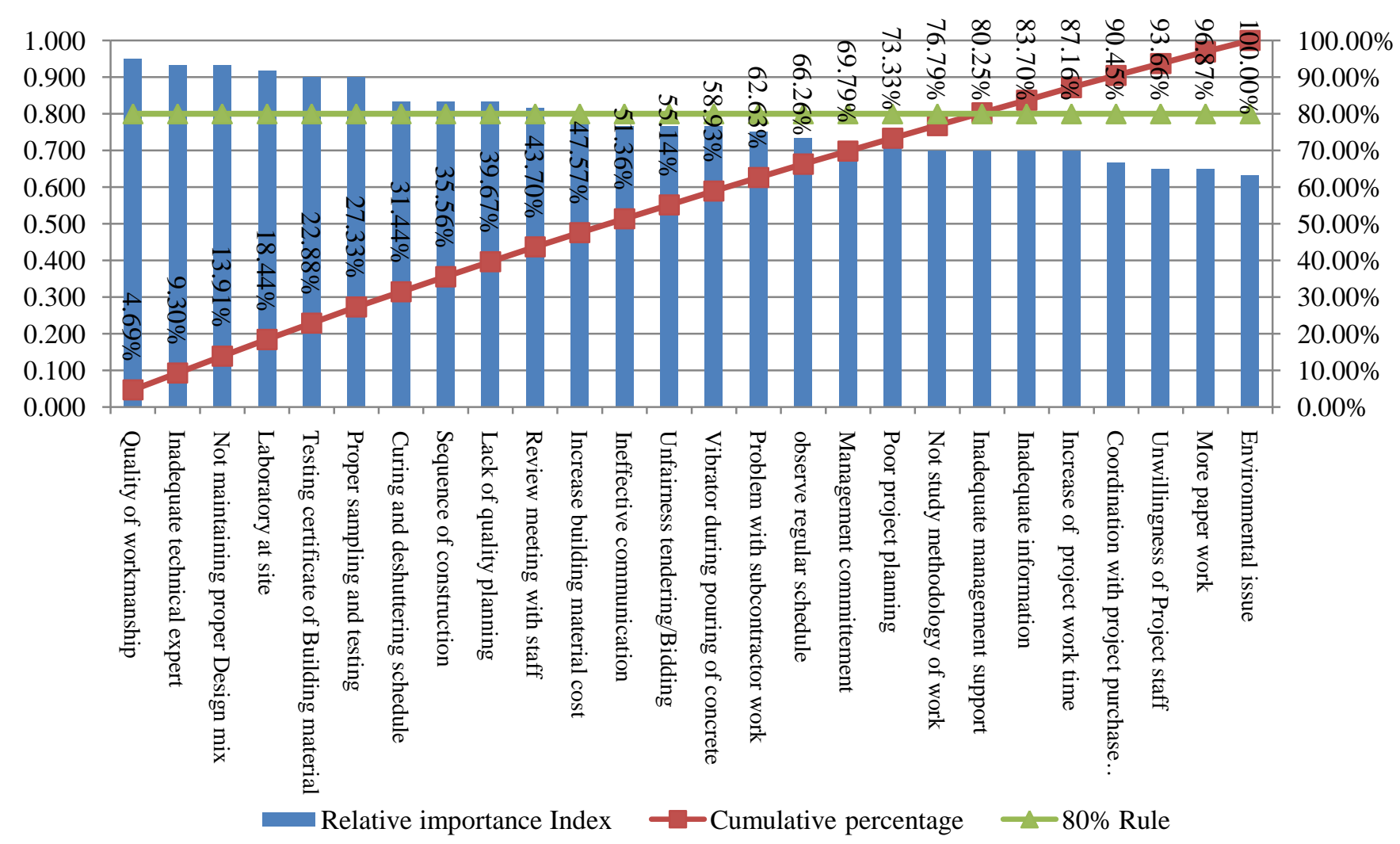

Fig-3: Pareto Chart

\subsection{Result and Discussion}

As stated in research methodology, questionnaires are circulated among the twenty project of a Construction company out of which twelve project of a construction company has responded. Rate of response is $60 \%$, which may be considered to be fair for data analysis. After examine the data of responses of respondents the following findings have been mentioned in detail.

As per Pareto Analysis (80-20) the major factors for quality control measure used in Building construction project is the quality of workmanship in all construction activities followed by Inadequate technical expert, Not maintaining proper Design mix, laboratory at site, Testing certificate of Building material, Proper sampling and testing, Curing and deshuttering schedule, Sequence of construction, Lack of quality planning, Site review meetings with staff, Increase Building material cost, Ineffective communication, Unfairness in tendering/Bidding, Vibrator during pouring of concrete, Problem with subcontractor work, Observe regular schedule, Management commitment, Poor project planning, Not study methodology of work, Inadequate management support.

The research also indicates that quality planning, quality control and quality assurance are the main elements for success of building construction project. It is necessary to give attention towards all these elements.

\section{CONCLUSION AND FUTURE SCOPE}

\subsection{Conclusion of Research}

In this study, identifying the major factors faced in building construction project is based on collecting information from different respondent and also finding their sequences from Relative Importance Index method for quality control measure used in Building construction project.

In this research, twenty major factors are most significant factors for quality control measures used in building construction project and respondents strongly believe that quality of workmanship in all construction activities are main quality control measures used on site followed by Inadequate technical expert, Not maintaining proper Design mix, Laboratory at site, Testing certificate of Building material, Proper sampling and testing, Curing and deshuttering schedule, Sequence of construction, Lack of quality planning, Site review meetings with staff, Increase building material cost, Ineffective communication, Unfairness in tendering/Bidding, Vibrator during pouring of concrete, Problem with subcontractor work, Observe regular schedule, Management commitment, Poor project planning, Not study methodology of work, Inadequate management support.

In building construction project quality control is very challenging job for project manager. The track record to maintain quality has not been good on site. The aim of this 
research is also to implement the quality tools. In this research, Pareto Analysis tool has been used to identify the major factors for quality control measure. Before implement quality tools firstly identify the sequence of the major factor by using Relative Importance Index method. From this research, by adopting Pareto Analysis(80-20 Rule) found that $80 \%$ quality problem measure/ improve by implementing 20 major factors on site. Further $20 \%$ quality problem improve by implementing remaining factors.

The case study research includes interviews, discussions with construction managers, detailed study of project documents and contracts. Company has own quality assurance plan and maintain quality as per contract. In this research, Relative Importance Index and Pareto analysis has been introduced for interpretive the quality factor to improve the quality of Group Housing Residential Apartment project. Result shows that fourteen factors out of which twenty factors already implemented at site to achieve quality of the project, therefore overall quality is reliable. Further suggest that quality can be improved in high rise building construction project by implementing remaining factors. The aim of this research to give more importance on quality to save time and cost of the project.

\subsection{Future Scope of Research}

The result of this research will help to the building construction project companies in India to understand how to implement the concept of quality control tool \& management more effectively, in order to develop and improve the performance of their tasks. This quality control tool will help that by offering quality assurance and quality control in India as a new management system concept within developing countries.

\section{REFERENCES}

[1]. Hakim Mohamed(1997) "Total Quality Management In Construction Projects”, .journal Technology, vol.(27), Dec. 1997

[2]. Ying Cao (2010) "Quality Control of Construction Projects".Savonia university of Applied science,Jouranal May 2010.

[3]. Nashwan Mohammed Noman Saeed et al (2012) "The Effect Of Total quality Management On Construction Project Performance" Journal of Science \& Technology Vol. (17) No. (2) 2012.

[4]. Faisal Talib (2013) “ An Overview of Total Quality Management: Understanding the Fundamentals in Service Organization" International Journal of Advanced Quality Management 2013, Volume 1, Issue 1, pp. 1-20, Article ID Mgmt-58.

[5]. Neha Kalra \& Anoop Pant (2013) “Critical Success Factors of Total Quality Management in the Indian Automotive Industry (NCR)" International Journal of Economy, Management and Social Sciences, 2(8) August 2013.

[6]. P.P.Mane \& J.R.Patil (2015) "Quality Management System at Construction Project: A Questionnaire Survey"
Int. Journal of Engineering Research and Applications ISSN : 2248-9622, Vol. 5, Issue 3, ( Part -3) March 2015.

[7]. Dr. Hellen Mberia et al (2015) "Evaluation Of Factors Influencing Total Quality Management Implementation In Rwadan Construction Companies: Case Of Fair Construction Company" European Journal of Business and Social Sciences, Vol. 4, No. 03, June 2015.

[8]. R.Lakshmi (2015) "Quality Control and Quality Assurance In Building Construction" National Conference on Research Advances in Communication, Computation, Electrical Science and Structures (NCRACCESS-2015).

[9]. Dheeraj A Bumb \& D. M. Ghaitidak(2016) "Study of Quality Assurance and Quality Management System in Multistroyed RCC Building", International Journal of Innovative Research in Science, Engineering and Technology vol. 3, Issue 5.

[10]. Dheeraj A Bumb \& D. M. Ghaitidak(2016) "Study of quality management system in Multistroyed RCC Buildings", International Journal of Innovative Research in Science, Engineering and Technology 8 (07).

\section{BIOGRAPHIES}

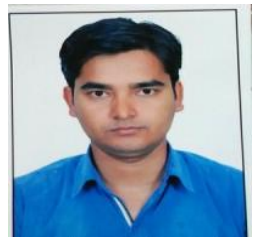

Md Afsar Ali, M.Tech Construction Technology \& Management, Al-Falah University, Haryana, India Email: afsarcivil@gmail.com Mobile: 9953567007

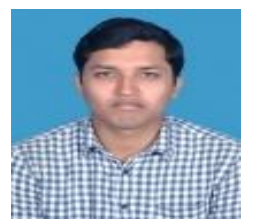

Masoom Reza, Assistant Professor, Civil Engineering Department, Al-Falah University, Haryana, India 